and doctoral fellowship's levels, the summer stipend is at the rate of $\$ 170$ per week, not to exceed a total of $\$ 1,020$. In addition, $\$ 600$ is granted for each dependent for the academic year and $\$ 120$ for the summer, plus travel expenses to and from the institution for the Fellow only.

The institution receives $\$ 2,500$ for each Fellow to help defray the cost of instruction during the academic year and $\$ 500$ for the summer.

Students seeking fellowships should apply directly to the participating institutions (as listed below), which will have sole responsibility for selecting recipients.

University of California (Los Angeles) 13

University of California (Berkeley) $\quad 17$

University of Southern California

(Los Angeles)

University of Denver

Catholic University (D.C.)

Florida State University (Tallahassee) 20

Atlanta University (Ga.) _ . . 12

Emory University (Ga.) @ 10

University of Hawaii (Honolulu) $\quad 15$

Rosary College (IIl.) 12

University of Chicago . $\quad 22$

University of Illinois $\quad 22$

Indiana University $\quad 22$

Kansas State Teachers College _ . 15

University of Kentucky $\quad 10$

Louisiana State University . . . 10

University of Maryland . . . 21

Simmons College (Mass.) . . 15

University of Michigan . . 12

Western Michigan University . . 5

University of Minnesota . 27

Rutgers, The State University (N.J.) 22

Columbia University . . . , 21

Pratt Institute. 10

State University of New York . $\quad 8$

Syracuse University _. . 15

Kent State University (Ohio) . . . 10

Western Reserve University (Ohio) 10

University of Oklahoma _ . . 5

University of Oregon $\quad 6$

Drexel Institute of Technology (Pa.) $\quad 10$

University of Pittsburgh . . 5

George Peabody College for Teachers (Tenn.)

North Texas State University

Our Lady of the Lake College (Tex.)

University of Washington

University of Wisconsin

\section{MSJCFA LIBRARIANS SECTION}

The Minnesota State Junior College Librarians section of MSJC Faculty Association met during the association convention on April 20. Moderator of a roundtable panel was James Holly, Macalester College. There were discussions by Richard White on federal grants applications, Raymond Bohling on the ALA Standards for Junior College Libraries, Donald Wujcik on state purchasing procedures and bidding procedures on periodicals, Mr. Holly on centralization of certain common procedures, and Bill Price on audio-visual services. The Minnesota State Junior Faculty Association Librarians Section has gone on record as endorsing the ALA Standards for Junior College Libraries, and has recommended that the State Junior College Board acknowledge, support, and implement these Standards.

\section{HONORED}

William Dex, librarian of Princeton University, was awarded an honorary Doctor of Laws degree by the University of Florida on April 23. The citation of his service read in part as follows:

Dr. Dix has been chosen repeatedly by his colleagues in the Association of Research Libraries for positions of leadership. Most recently, he served as chairman of the committee which planned and enlisted the cooperation of research libraries in this country and Europe in establishing national centers for world-wide acquisition and cataloging of research materials. As a result of his efforts, the Library of Congress will hence forth serve the libraries of the United States in the acquisition and cataloging not only of American library materials but of materials from the entire world. It would be difficult to over-emphasize the importance of his achievement as an aid to scholarly research and in savings in cost to the cooperating libraries. We owe a debt of gratitude to the librarians of these libraries, and especially of the Library of Congress, for this collaborative effort, but the guiding mind and spirit has been that of William Shepherd Dix. 


\section{TITLE II ORDERS}

Taylor-Carlisle is now accepting orders under the Title II Program, which will be billed, shipped and dated as per your specifications.

Our liberal discount policy applies to all orders.

Hope to see you at the ALA convention. We're looking forward to greeting old friends and new at Booth 906.

Address all Title II orders and correspondence to:

Title II

\section{Taylor-Carlisle}

115 East 23rd St., New York, N.Y. 10010

or to

Title II

Florida's Taylor-Carlisle

Winter Park Mall, Winter Park, Florida 